\title{
29. BIOSTRATIGRAPHY OF MIOCENE DEEP-SEA SEDIMENTS (SITES 372 AND 375), WITH SPECIAL REFERENCE TO THE MESSINIAN/PRE-MESSINIAN INTERVAL
}

\author{
Maria Bianca Cita, University of Milano, Milano, Italy \\ Maria Luisa Colalongo and Sara d'Onofrio, University of Bologna, Bologna, Italy \\ Silvia Iaccarino, University of Parma, Parma, Italy \\ and \\ Gianfranco Salvatorini, University of Pisa, Pisa, Italy
}

\begin{abstract}
Planktonic foraminifers from the Mediterranean Evaporite cored at Site 372 (Balearic Basin) are referable to Zone N.17 of the standard zonation. A major hiatus, corresponding to a duration of over 6 m.y., is documented at the base of the varved interval recovered in Section 2 of Core 9, at approximately 199.5 meters subbottom. The hemipelagic sediments underlying the varved interval are referred to the latest part of Zone N.13, close to the Globigerina nepenthes datum, which defines the N.13/N.14 zonal boundary; they are Serravallian.

The hemipelagic sediments with turbidites underlying the Mediterranean Evaporite recorded in the Levantine Basin (Site 375) are of late Tortonian age: foraminiferal Zones N.17 and N.16 were identified.
\end{abstract}

\section{FOREWORD}

Leg 13 of the Deep Sea Drilling Project led to the discovery that evaporites similar in their facies and stratigraphic position to those outcropping in Sicily, in peninsular Italy, and in other circum-Mediterranean areas such as southern Spain, northern Algeria, and the Greek islands, are present beneath the floor of all the major basins of the Mediterranean (i.e., Balearic, Tyrrhenian, Ionian, and Levantine; see Ryan, Hsü, et al., 1973). Only the upper part of the Mediterranean Evaporite was penetrated during Leg 13; foraminiferal faunas referable to Zone N.17 occur consistently in the marls interbedded with the evaporites in the western Mediterranean drillsites (Cita, 1973).

Investigations into the deep-sea expression of the late Miocene "salinity crisis" were further developed during Leg 42A of the Deep Sea Drilling Project. This scientific expedition offered the opportunity to investigate, from the deep-sea record, biostratigraphy and facies of the sediments predating the onset of the "salinity crisis."

The purpose of this paper is to present a detailed biostratigraphic study of the Messinian and preMessinian sediments recovered at Site 372 (east of Menorca in the Balearic Basin) and at Site 375 (west of Cyprus in the Levantine Basin), including a correlation with the stratotype sections. At these sites, penetration continued below the Mediterranean Evaporite, which in both cases is only approximately 50 meters thick (pinch-out at the edge of the basin), into hemipe- lagic sediments very rich in planktonic foraminifers. Foraminiferal faunas were also recorded within the evaporite.

Whenever possible, three different zonal schemes based on planktonic foraminifers were applied: Blow's (1969) standard scheme; that of Bizon and Bizon (1972), based on Mediterranean foraminiferal faunas; and that recently proposed by d'Onofrio et al. (1975). The d'Onofrio biozonation has been proposed for the Tortonian-Messinian interval, as materialized in several sections measured from the Piedmont Basin to Sicily, in connection with a study undertaken to define and correlate the base of the Messinian stage (or Tortonian/Messinian boundary). With reference to the Messinian neostratotype (Selli, 1960), in fact, neither the boundary stratotype approach, nor the biostratigraphic approach can be applied successfully (Cita et al., 1973; d'Onofrio et al., 1975).

The senior author, who was shipboard paleontologist during Leg $42 \mathrm{~A}$, shared the study of this interesting material with some of her colleagues, who are conducting a multidisciplinary research project funded by Consiglio Nazionale delle Ricerche of Italy in order to investigate the geodynamic significance of the late Miocene salinity crisis in the Mediterranean, and who dedicated much of their activity in the last two years to improve the biostratigraphic resolution of just that interval.

Since descriptive paleontology involves some subjective appreciation of the taxonomic characters, a joint paper is inevitably a compromise. Here it is a generally 
agreed upon, long-discussed compromise which was considered satisfactory by all five authors.

\section{BIOSTRATIGRAPHY}

\section{Site 372}

At this drillsite coring was continuous (see Figure 1 ), but core recovery was very poor for Cores 4 through 8 , where strongly diversified lithologies, including indurated rocks, occur. Fifty-three samples have been investigated from the approximately 90 meter-thick interval (Cores 13 through 4). Figure 2 shows the distribution of selected foraminiferal species in these samples.

For the sake of clarity, we will discuss separately (a) the interval from Sample 13, CC to Sample 9-2, 60-62 $\mathrm{cm}$, which interval is characterized by hemipelagic sediments with uniform lithology and fossil content, and (b) the interval from Sample 9-2, 40-42 cm to Sample 4-1, 61-62 cm, which includes the sedimentary expression of the late Miocene salinity crisis.

\section{Interval From Sample 13, CC to Sample 9-2, 60-62 cm}

The zonation recently proposed for the Tortonian/ Messinian interval (d'Onofrio et al., 1975) could not be applied here, because no sediments corresponding in age to those considered in d'Onofrio's paper are

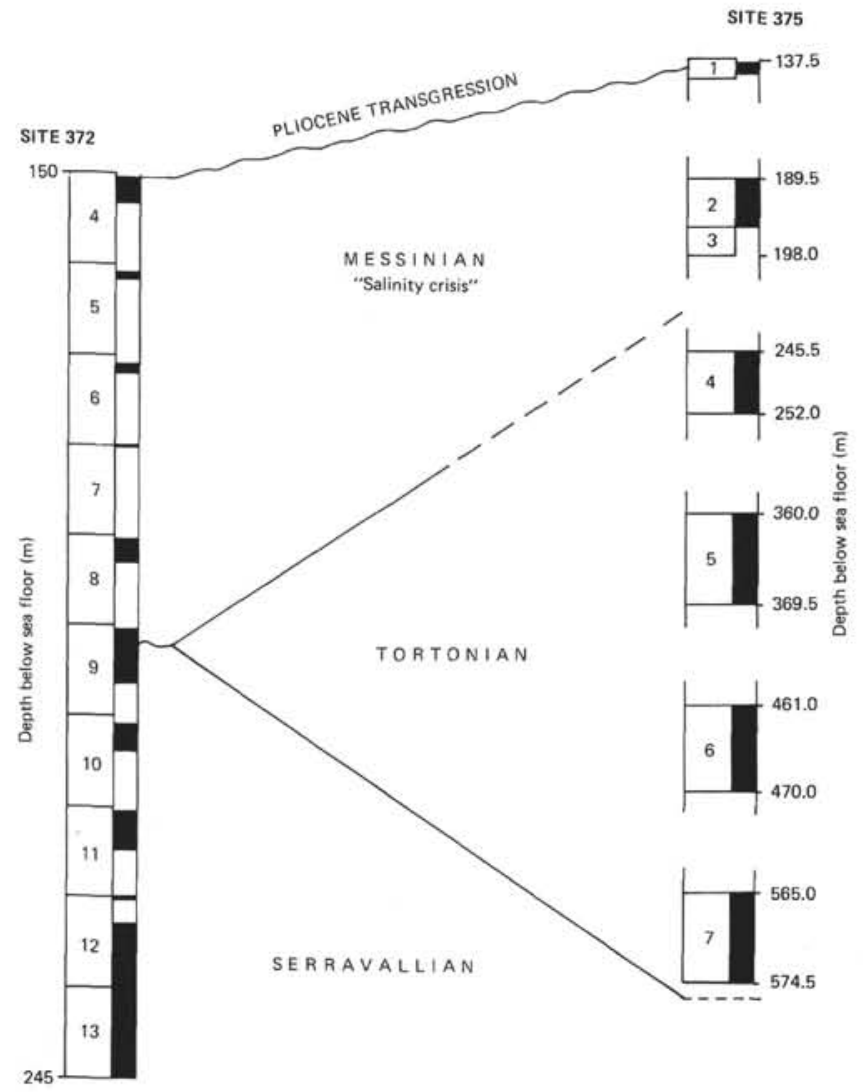

Figure 1. Correlation of the middle and upper Miocene sections investigated from Sites 372 (Balearic Basin) and 375 (Levantine Basin). present at Site 372. Consequently, we only applied the zonations by Blow (1969) and Bizon and Bizon (1972), which both present some difficulties in application.

1) The presence, from the lowermost sample considered here, of Sphaeroidinellopsis subdehiscens subdehiscens (first recorded at Site 372 in Sample 15-4, 40$42 \mathrm{~cm}$ ) without Globigerina nepenthes, indicates that the interval under discussion is referable to Zone N.13, defined as the interval between the first occurrence of S. subdehiscens subdehiscens and the first occurrence of $G$. nepenthes. This zone assignment is supported by the occurrence, up to the topmost part of the hemipelagic sediments here considered, of Globigerinoides subquadratus, Globigerinopsis aguasayensis, and Globorotalia praemenardii praemenardii (the last one in a nontypical form only in Core 9): all these taxa disappear in Zone N.13. It is also supported by the first occurrence of Globigerina decoraperta (a taxon first recorded from Zone N.13) in Sample 12-3, 14-16 cm. Finally, it is supported by the disappearance of Globorotalia mayeri (sensu Blow, 1969; not sensu Bolli, 1957; Postuma, 1971; Bizon and Bizon, 1972) in Section 5 of Core 12 , which taxon disappears in about the middle of Zone N.13.

It is worth mentioning at this point how difficult it is to define the lower boundary of Zone N.14, because of the inherent difficulties in pinpointing the first evolutionary occurrence of Globigerina nepenthes in the slow and gradual evolution from $G$. druryi. This difficulty also results from the pertinent literature. In fact, Bolli (several papers) and Blow (1969) indicate a time gap between the topmost occurrence of Globorotalia fohsi s.l. (an unambiguous, readily recognizable taxon) and the first record of Globigerina nepenthes, whereas Jenkins and Orr (1972), Berggren and Amdurer (1973), and Srinivasan (1975) record an overlap in the range of these two taxa. Our shared opinion is that no typical specimens of $G$. nepenthes occur up to the topmost part of the interval under discussion, but only highly evolute forms of $G$. druryi.

One further, though weak, indication of the N.13 Zone is the scattered occurrence of Cassigerinella chipolensis, which becomes extinct within this zone.

The genus Globoquadrina is consistently well represented and fairly diversified; common taxa are $G$. altispira (group), G. dehiscens (group), and G. baroemoenensis. Globorotalia siakensis (see Taxonomic Notes) and $G$. continuosa range throughout the inter$\mathrm{val}$, and are often well represented. Among the keeled globorotaliids, two groups are prominent: G. praemenardii praemenardii with related forms (see Taxonomic Notes) and G. miozea miozea/G. miozea conoidea. The latter taxon, which derives from the former, occurs from Sample 10-2, 50-52 cm upward.

Within the genus Globigerina, abundant G. bulloides s.l. occurs in the entire interval, abundant $G$. falconensis and $G$. decoraperta in its middle-upper part.

Also well represented is the genus Globigerinoides, with G. quadrilobatus (group) and G. subquadratus. The genus Orbulina is consistently well represented; 


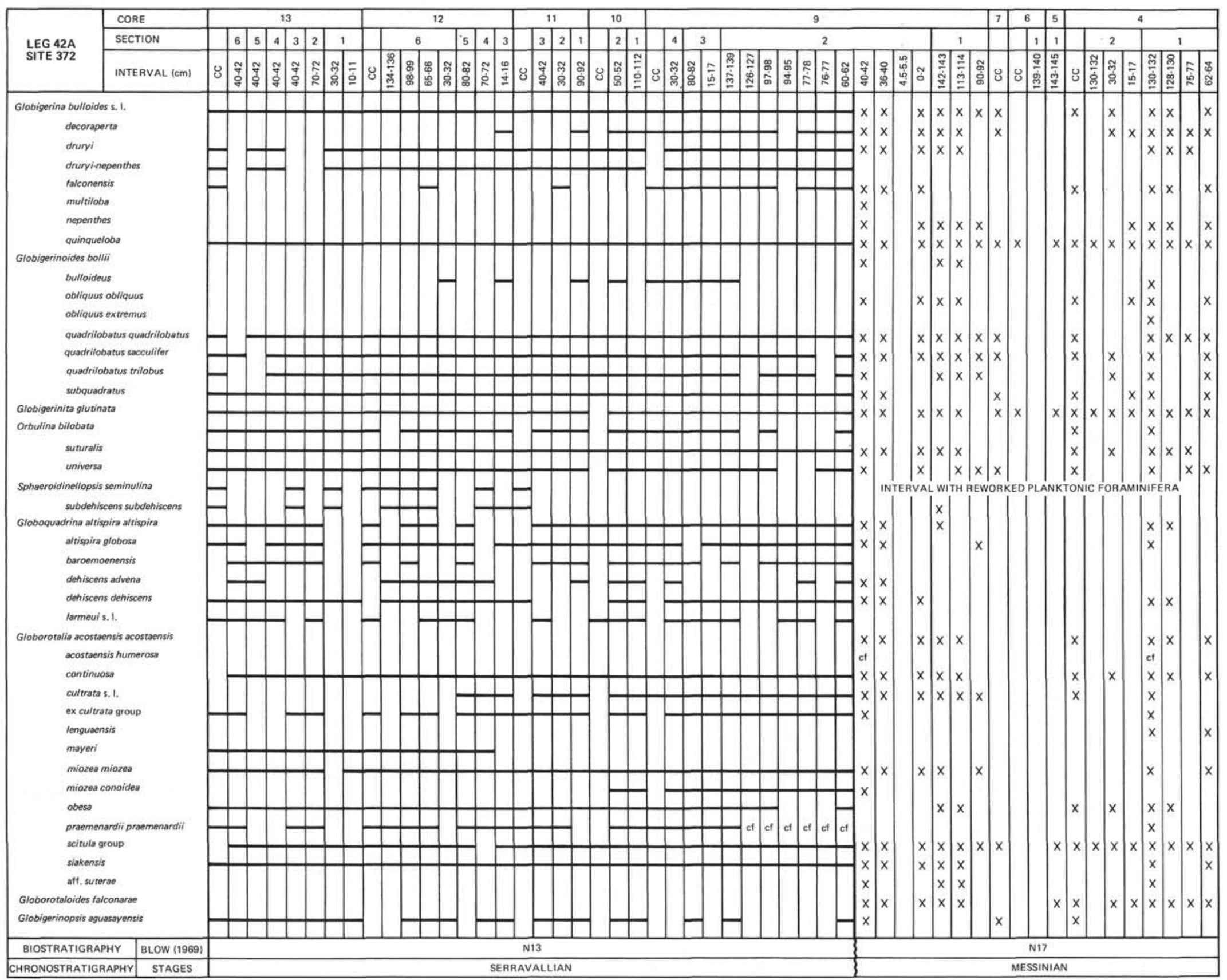


Sphaeroidinellopsis is scattered and limited to the middle-lower part of the interval, and Globigerinopsis is just occasional.

2) With reference to the biozonation of Bizon and Bizon (1972), the same interval is referable to the later part of the Globorotalia mayeri Zone. The topmost record of $G$. peripheroronda, whose last occurrence is used to define the lower boundary of the G. mayeri Zone, is in Sample 21-6, 40-42 cm, or well below the lowermost sample discussed here. The upper boundary of the G. mayeri Zone (sensu Bizon and Bizon) is defined by the last occurrence of the zonal marker. We found G. mayeri up to Core 12, Section 5, as discussed above. However, the Bizon and Bizon interpretation of G. mayeri is much broader than our own, and includes forms which we refer to $G$. siakensis. Since the latter taxon is consistently present in the topmost part of the hemipelagic sediments in Section 9-2, we do not find clear post-G. mayeri Zone evidence in the interval under discussion.

Interval From Sample 9-2, 60-62 $\mathrm{cm}$ to Sample 4-1, $62-64 \mathrm{~cm}$

The samples examined generally yield an abundant inorganic fraction, consisting of quartz grains, feldspar, glauconite, mica flakes, and gypsum crystals. This holds true in particular for the finely laminated (varved) interval from the topmost part of Sample 9-2, $40-42 \mathrm{~cm}$. The planktonic foraminiferal faunas are sparse, often small. Worn specimens are common. Some samples are devoid of foraminiferal tests. The stratigraphic indications given by the fossiliferous samples are often inconsistent (see Figure 2), suggesting extensive reworking.

Besides these general comments, and with reference to the samples from $9-2,40-42 \mathrm{~cm}$ to $7, \mathrm{CC}$, planktonic foraminifers are consistently associated with Ammonia beccarii tepida, whose tests are beautifully preserved. This benthic foraminifer has a depth distribution and a salinity tolerance suggestive of a depositional environment entirely different from the open ocean where planktonic foraminifers do live (see Cita, Wright, Ryan, and Longinelli, this volume).

The above observational data indicate that some, if not all, the planktonic foraminifers in this interval may be reworked. Under these circumstances, a precise biostratigraphic assignment is not possible. We will instead discuss the biochronological constraints given by the recorded occurrence of individual taxa having restricted or significant ranges.

In the lowest sample investigated from this interval (9-2, 40-42 cm), we were able to identify the following taxa, on which each of the five authors agreed: Globigerina bulloides s.str., Globorotalia acostaensis acostaensis, $G$. aff. suterae, and specimens very like G. acostaensis humerosa. The ranges of these species, as given by Blow (1969) and as shown by our personal experience on various Mediterranean sections, indicate that they occur first at different levels within Zone N.16. The occurrence, in this sample, of Globigerina multiloba (Figure 3 ) is an excellent indication for Zone N.17, later part. D'Onofrio et al. (1975) discuss the chronological significance of this taxon.

The same faunal assemblage, with reworked specimens, is present up to Core 4 .

The topmost sample investigated from this interval $(4-1,62-64 \mathrm{~cm})$ yields a heterogeneous assemblage of Miocene and Pliocene taxa. Among the latter, which are not included in Figure 2, we mention here Globorotalia puncticulata, G. margaritae (group), G. crassaformis aemiliana, G. crassaformis crassaformis, G. sphaericomiozea, and $G$. inflata. We consider this admixture a drilling artifact.

In conclusion, the whole interval is referable to Zone N.17 (upper part). It follows from the above that between Samples 9-2, 60-62 $\mathrm{cm}$ and 9-2, 40-42 $\mathrm{cm}$ we have a gap which, in terms of Blow's zonation, encompasses the interval N.14-N.17 (pars).

It also follows from the above that marine sediments as young as the upper part of Zone N.17 were exposed in nearby slopes subject to erosion during deposition of the laminites.

\section{Site 375}

Coring was discontinuous (see Figure 1). The lithology of Cores 1-3 (Mediterranean Evaporite) was unsuitable for the study of planktonic foraminifers. Thirty samples were investigated from Cores 4 through 7. Figure 4 shows the distribution in these cores of selected, stratigraphically significant or common, foraminiferal species.

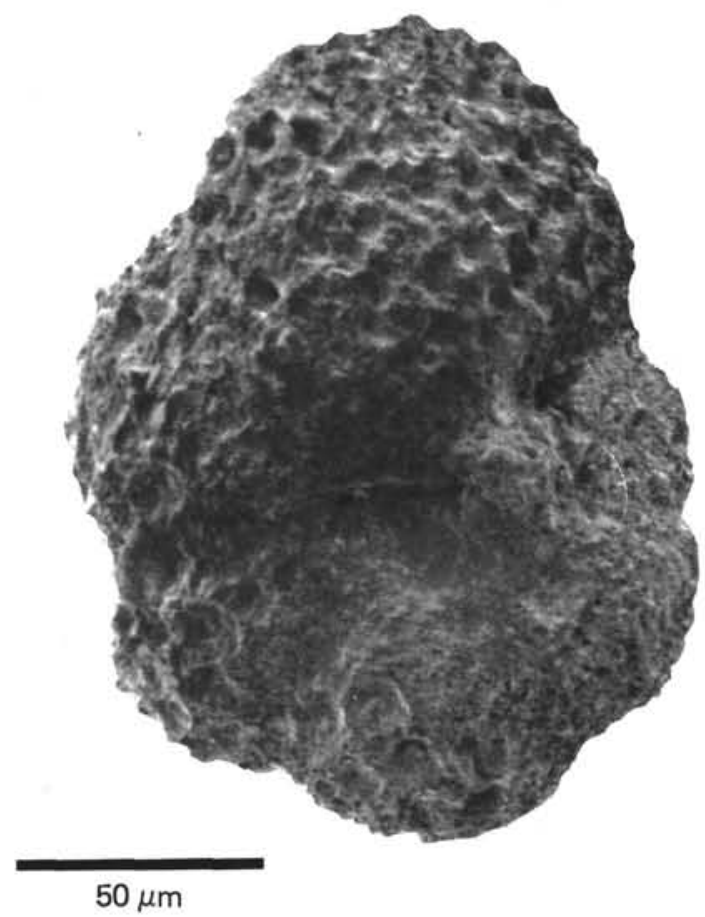

Figure 3. Globigerina multiloba Romeo, umbilical view. Sample 372-9-2, 40-42 cm. Base of the varved interval, Messinian, Zone N.17. 


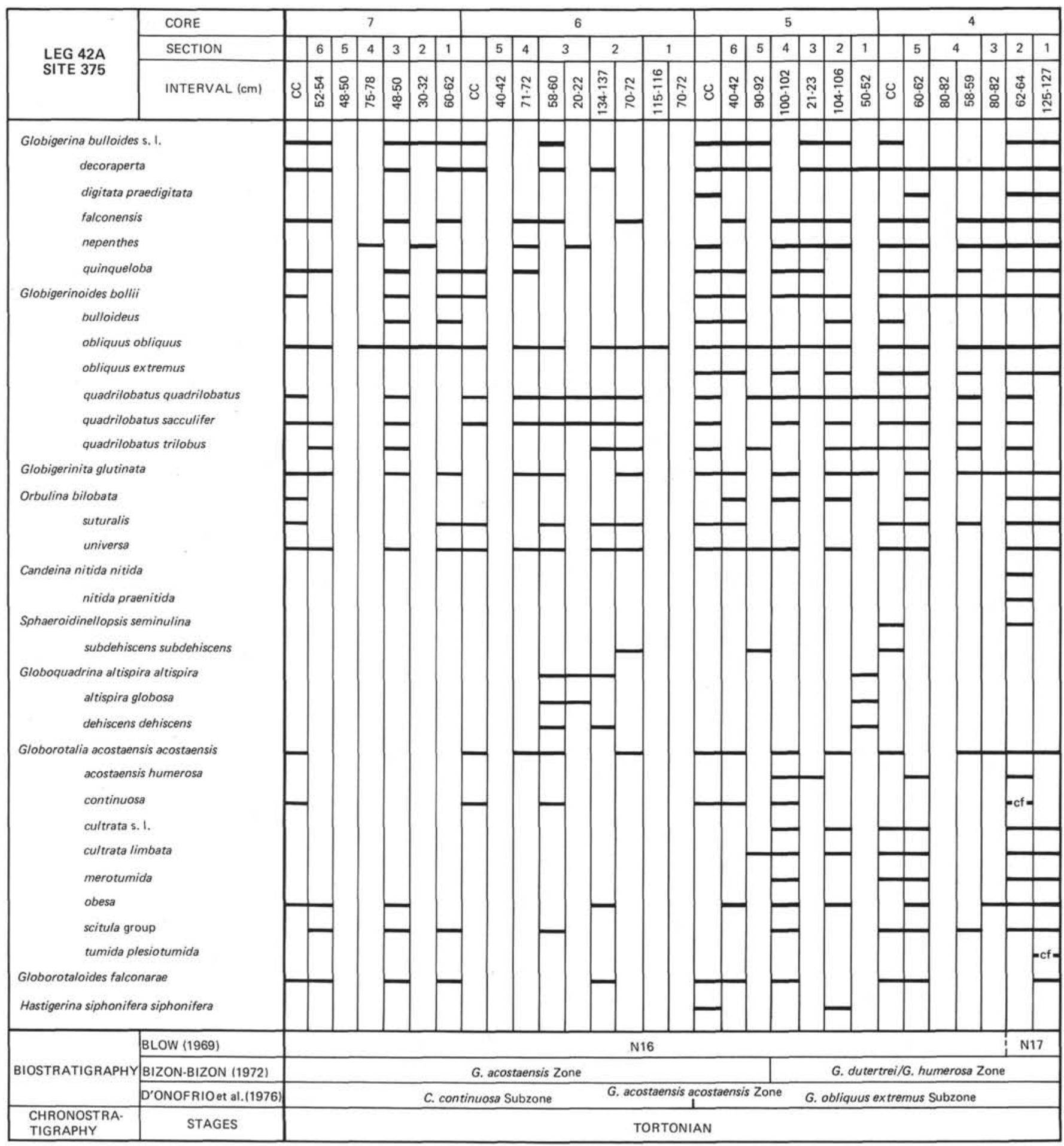

Figure 4. Distribution of 35 taxa of planktonic foraminifers in Cores 4-7, Site 375.

1) With reference to the biozonation of d'Onofrio et al. (1975), the entire interval, some 330 meters thick, is referable to the Globorotalia acostaensis acostaensis Zone. We identified the following subzones, from bottom to top:

Globorotalia continuosa Subzone. This subzone, defined as the interval from the first occurrence of $G$. acostaensis acostaensis to the first occurrence of Globig- erinoides obliquus extremus, is represented in Cores 7 and 6. The interval is very rich in turbidites: some samples are practically barren (e.g., 7-5, 40-42 cm; 7-4, $75-77 \mathrm{~cm} ; 6-5,40-42 \mathrm{~cm})$. The foraminiferal faunas are generally poor and occasionally contain reworked specimens. Besides the (sub) zonal marker, Globorotalia acostaensis acostaensis, G. scitula (group), Globigerina decoraperta, G. nepenthes, $G$. falconensis, Globig- 
erinoides obliquus obliquus, G. bollii, and Globorotaloides falconarae also occur.

Globigerinoides obliquus extremus Subzone. This subzone, defined as the interval from the first occurrence of the (sub)zonal marker to the first occurrence of Globorotalia suterae, is present in Cores 5 and 4. This interval, unlike the previous one, yields rich and diversified fossil assemblages. The normal sedimentation was occasionally interrupted by stagnant cycles, resulting in the deposition of black layers (sapropels), rich in organic matter, which yield numerous spores, as for instance Samples 5-3, 21-23 cm and 4-4, 58-59 cm. Only Sample 5-2, 104-106 cm, among those analyzed, contains evidence of turbiditic input (benthic, planktonic foraminifers and other biogenic fragments worn, reworked; several discrete minerals also with worn surfaces).

The (sub)zonal marker is consistently recorded, along with Globigerinoides obliquus obliquus, G. bollii, and G. quadrilobatus (group). Among representatives of the genus Globorotalia, it is worthwhile to mention the occurrence of $G$. acostaensis humerosa and of keeled forms ( $G$. merotumida, G. cultrata s.l., G. cultrata limbata, and G.cf.tumida plesiotumida, the last species recorded only in Sample 4-1, 125-127 cm). Keeled globorotaliids are locally very well represented. Globigerina nepenthes, G. falconensis, Globorotaloides falconarae, and the group of Globorotalia scitula are also abundant in this interval. Occasional and scarce are Hastigerina siphonifera siphonifera, Candeina nitida nitida, C. nitida praenitida, and Globorotalia continuosa.

2) With reference to the zonal scheme of Bizon and Bizon (1972), the recorded occurrence of Globorotalia acostaensis humerosa from Sample 5-4, 100-102 $\mathrm{cm}$ permits us to distinguish the following:

Globorotalia acostaensis Zone: from Sample 7, CC to Sample 5-5, 90-92 cm.

Globorotalia dutertrei/G. humerosa Zone: from Sample $5-4,100-102 \mathrm{~cm}$ through Core 4.

3) With reference to Blow's zonal scheme, we have the following distinctions:

N.16 Zone: from Sample 7, CC to Sample 4-3, 80$82 \mathrm{~cm}$. The assignment is well founded. In fact, from the very first (lowermost) sample here considered, the zonal marker is present along with Globigerina bulloides s.str. Globorotalia acostaensis defines with its first occurrence the lower boundary of Zone N.16, whereas the latter occurs first in the lower part of Zone N.16. We noted within this interval the first occurrence of the following taxa, from bottom to top: Globigerinoides obliquus extremus, Globigerina digitata praedigitata, and Globorotalia acostaensis humerosa. These findings are consistent with the ranges of the taxa, as shown and discussed by Blow (1969).

N.17 Zone: upper part of Core 4, from Sample 4-2, 62-64 $\mathrm{cm}$ upward. The interval mentioned from Section 2 yields Candeina nitida nitida, whose evolution from its ancestor $C$. nitida praenitida is recorded in the lowermost part of Zone N.17. The uppermost sample investigated from this interval $(4-1,125-127 \mathrm{~cm})$ also yields a rich population of keeled globorotaliids, including forms identified as $G$. cf. tumida plesiotumida. The problem of this taxon, marker fossil of Zone N.17, is discussed in the Taxonomic Notes.

\section{CHRONOSTRATIGRAPHY}

\section{Site 372}

The chronostratigraphic position of the foraminiferal faunas, indicating open marine conditions, bathyal depths, normal salinities, and eutrophic, normal environment, recorded from Core 13 to Section 9-2 beneath the varved interval, is clear and unambiguous. In the previous pages we have discussed at length the multiple and consistent biostratigraphic bases leading to the assignment of this interval to Zone N.13. This biozone has been recognized in the Serravallian stage, which extends from Zone N.10 to Zone N.15 (pars), as shown by Cita and Blow (1969) and discussed in Ryan et al. (1974). We count here only some of the strongest arguments supporting the above positioning:

Consistent occurrence of Globigerinoides subquadratus, which becomes extinct in the topmost part of Zone N.13.

Consistent occurrence of Globorotalia praemenardii praemenardii, with highly evoluted forms in Core 9 (this taxon also becomes extinct in Zone N.13).

Absence of typical Globigerina nepenthes, whose first occurrence is considered characteristic for the N.13/N.14 zonal boundary. Its ancestor $G$. druryi is consistently recorded, with highly evolute forms in Core 9.

We investigated in detail the hemipelagic marls immediately underlying the finely laminated (varved) interval, to check whether the approximately $60-\mathrm{cm}$ thick portion of that core-which has several unusual features, such as (1) faint, white laminations, (2) white spots or "clouds" and (3) large concretions (see Cita, Wright, Ryan, and Longinelli; this volume)-contains a condensed sequence or shows evidence of strong reworking. In fact, a hiatus corresponding to several million years occurs there. According to Ryan et al. (1974), the Globigerina nepenthes datum has an interpolated age of $12.7 \mathrm{~m} . \mathrm{y}$. and the onset of the Messinian "salinity crisis" occurred 6.2 m.y. ago. The sedimentary expression of some 6 m.y. is thus missing at Site 372 . Whether this hiatus is a local phenomenon related to the peculiar setting of the drillsite, or is of regional importance, is not pertinent here.

Our observational data on the immediately prevarved interval indicate that normal open-marine conditions persisted to the top of the unit; the sand-size fraction of the sediment is usually very small, biogenic, without peculiarities. Radiolarians have been noticed at $60 \mathrm{~cm}, 76-77 \mathrm{~cm}, 77-78 \mathrm{~cm}$ in Section 9-2. Fish teeth and ostracodes occur at $76-77 \mathrm{~cm}$ of the same section.

The presence of this major gap prevents us from tracing the faunal and environmental evolution in the earlier part of the late Miocene.

Because of the occurrence of typical Globigerina multiloba in the lowermost sample investigated from 
the varved interval, we can demonstrate that this part of Section 9-2, as well as the overlying cores up through Core 4 , are assignable to the upper part of Zone N.17, which encompasses the Messinian stage (see Cita and Blow, 1969; Catalano and Sprovieri, 1969, 1971; Colalongo, 1970; Cita, et al., 1973; Ryan et al., 1974; d'Onofrio et al., 1975).

\section{Site 375}

All four cores investigated from this drillsite are Tortonian. They extend from the middle-lower Tortonian to the lower part of the upper Tortonian, according to the stratotype section (Gianotti, 1953; Cita et al., 1965; Cita and Blow, 1959; Ryan et al., 1974). In particular, Cores 7 and 6 postdate the Globorotalia acostaensis datum and the Globigerinoides obliquus extremus datum. According to the type-section, the position of this interval is approximately between levels 4 and 5 of Cita et al. (1965), see Figure 5.

Cores 5 and 4 postdate the Globigerinoides obliquus extremus datum and predate the Globorotalia suterae datum, which has been identified in sample RM 10 of d'Onofrio et al. (1975), and which comes from a level corresponding roughly to level 11 of Cita et al. (1965). It follows from the above that the interval encompassing Cores 5 and 4 can be correlated with the interval encompassing levels 6 to 11 of Cita et al. (1965). This correlation supports the assumption formulated by Giannelli and Salvatorini (1975) and by d'Onofrio et al. (1975) that the base of Zone N.17 in the stratotype of the Tortonian stage falls in a position lower in the section than that admitted by Cita and Blow (1969).

\section{CONCLUDING REMARKS}

The main results of our study can be summarized as follows:

1) An important hiatus is present at the base of the varved interval in Section 9-2, Site 372. Sediments of Zone N.13 (Serravallian) immediately underlie sediments of upper Zone N.17 (Messinian). The time gap is of the order of some 6 m.y. Whether this hiatus has to be attributed to non-deposition or to erosion during an early stage of the salinity crisis will be discussed elsewhere.

2) The foraminiferal faunas from Site 372 marls interbedded with the Mediterranean Evaporite from Section 9-2 (above $50 \mathrm{~cm}$ ) to Core 4 indicate Zone N.17, or the same biozone identified at Leg 13 Sites 124,132 , and 134 within the Mediterranean Evaporite.

3) The well-founded correlations and chronologic assignments previously discussed permit us to conclude that the Mediterranean Evaporite cored in the Levantine Basin at Site 375 (Cores 1-3) correlates with the Mediterranean Evaporite (= Formazione Gessososolfifera) on land sections in Italy. In other words, open-marine deep-water sediments predating the onset of the salinity crisis belong to Zone N.17 in the farthest part of the eastern Mediterranean, as well as in the stratotype sections of the Messinian and Tortonian stages. Drilling during Leg 42A disproved the dia- chroneity of the Mediterranean Evaporite, postulated by several authors even after DSDP Leg 13 (see Symposium on Messinian Events in the Mediterranean, Drooger, 1973; Sonnenfeld, 1974, inter alias).

\section{TAXONOMIC NOTES}

\section{Globigerina bulloides s.l.}

Under this heading, besides $G$. bulloides d'Orbigny, we include $G$. bulloides praebulloides Blow and $G$. parabulloides Blow. Whereas $G$. bulloides s.str. is present throughout the interval investigated at Site 375 , it occurs only from Sample 9-2, 40-42 cm upward at Site 372. The two remaining taxa are ubiquitous at both sites.

\section{Globigerina digitata praedigitata Parker}

(Plate 1, Figure 13)

Specimens of this subspecies are present but sparse in the Globigerinoides obliquus extremus Subzone at Site 375. The specimens are small and represent primitive forms of this species, i.e., forms without a distinctly radial elongation in every chamber of the last whorl.

\section{Globigerina nepenthes Todd}

(Plate 1, Figures 6, 7)

Typical specimens of $G$. nepenthes Todd, comparable to both the holotype and to those figured by Bronnimann and Resig (1971) and by Stainforth et al. (1975), occur throughout the interval investigated at Site 375, and from Sample 9-2, 40-42 cm upward at Site 372. In the underlying section from Site 372 here considered, within the populations of $G$. druryi Akers (see Plate 1, Figures 1-3), small specimens occur which have several morphological features similar to $G$. nepenthes.. These forms are here considered transitional between the two species, which evolve from one another, and are plotted in the range chart of Figure 2 as G. "druryi-nepenthes" (see Plate 1, Figures 4, 5).

\section{Candeina nitida nitida d'Orbigny}

(Plate 1, Figure 12)

The two subspecies distinguished by Blow (1969) within the stratigraphic range of the genus Candeina, are separated essentially on the basis of the occurrence (in $C$. nitida nitida) of multiple apertures along the intercameral sutures preceding that separating the last chamber from the penultimate one (arrows in Figure 12, Plate 1), or on their absence (in C. nitida praenitida, see Figures 10 and 11 in Plate 1). If we accept this criterion of distinction, both subspecies are present in Sample 4-2, 62-64 cm, Site 375.

The sparse specimens of $C$. nitida nitida, however, lack the proliferation of the sutural apertures which characterizes the most advanced forms. Besides an umbilical bulla, occasional small bullae occur on some of the intercameral and spiral apertures.

\section{Genus Globoquadrina Finlay}

The genus is well represented at Site 375, and at Site 372 from Core 13 to Sample 9-2, 60-62 cm. In the overlying interval the occurrence of Globoquadrina is sporadic.

The taxa, as recorded in Figures 2 and 4, have been identified with strict reference to the original definitions (see Plate 3, Figures 1-7). We like to state here, however, that a careful revision of this genus is much needed, to achieve distinctions more realistic than those now used. We think that re-examination, taking into account intraspecific variability and evolutionary trends, would result in the rejection of several taxa.

Globorotalia acostaensis humerosa Takayanagi and Saito (Plate 4, Figures 7 and 11)

Sparse but typical specimens of this taxon occur in Cores 5 and 4 , Site 375 . They have a low trochospire, with five to six ovate chambers in the final whorl, separated by depressed, gently curved sutures both on the spiral side and on the umbilical side. The last formed chamber is sometimes slightly displaced towards the umbilical area. The aperture is a low arch and is borded by a thin lip. 
Less typical specimens ( $G$. cf. acostaensis humerosa in the range chart; see Figure 2) occur in Samples 9-2, 40-42 cm and 4-I, 130$132 \mathrm{~cm}$ at Site 372.

Globorotalia praemenardii - G. cultrata plexus (Plate 5, Figures 1-3, 4 and 8)

According to Blow (1969), G. cultrata cultrata (the "oldest" taxon belonging to the $G$. cultrata plexus) would evolve from $G$. praemenardii praemenardii Cushman and Stainforth within Zone $\mathrm{N} .11$; the evolution would result in the development of limbate intercameral sutures and of limbate spiral suture in the inner whorls. Our observations on the Site 372 taxa support Blow's conclusions on the progressive evolution of these morphological features: one of us (G.S.) indeed could find limbate sutures in the inner whorls, starting from Core. 17, Site 372, which is assigned to Zone N.11. However, the present authors do not concur with Blow (1969) in the distinction of subspecies within the G. cultrata plexus. In particular, we foundin accord with the observations of Giannelli and Salvatorini (1975) on the Miocene sections from Malta-that the form evolving from the typical $G$. praemenardii, showing limbate intercameral as well as sutural sutures beyond the last formed whorl (see Figure 5), shows a test morphology, and in particular a chamber morphology, still "praemenardii-like," in such a way that it cannot be identified with any of the subspecies or forms of either $G$. cultrata or $G$. menardii described in the pertinent literature (see Blow, 1969; Tjalsma, 1971; Zachariasse, 1975, inter alias). The evolutionary trends are such that when the sutural limbation reaches the cultrata stage, several morphological features are still in the praemenardii stage. As a consequence, if one accepts Blow's criterion to separate the globorotaliids of the G. cultrata group from those of the G. praemenardii group, one has also to include the form under discussion in the former. Such a form, temporarily designated as $G$. ex cultrata group, occurs from Core 17 to Sample 9-2, 60-62 cm at Site 372. Within this interval a gradual change occurs, from initial dominance of $G$. praemenardii praemenardii to dominance of G. cultrata; $G$. cultrata is particularly abundant in Core 12 . Within Core 12, the specimens assigned as $G$. ex gr. cultrata tend toward (1) larger size of the test, (2) increasing number of chambers in the last whorl, (3) lesser convexity of the spiral side, (4) greater roundness of the chambers in spiral view, (5) thickening of the peripheral keel and of the sutural limbation, and (6) wider umbilicus.

In other words, our findings support a transitional evolution towards globorotaliids of the $G$. cultrata group as traditionally intended; these forms are first recorded in Sample 12-5, 80-82 cm.

Owing to the essentially biostratigraphic orientation of the present paper, we have decided to retain from subdividing the plexus under discussion, and group the various morphotypes under $G$. cultrata s.l., with the one exception of $G$. cultrata limbata (Fornasini).

At Site 375, we recorded rich populations of this subspecies which closely correspond to the lectotype selected by Banner and Blow (1960) and to the observations of Blow (1969) and Cita (1971).

Globorotalia pseudomiocenica Bolli and Bermudez is here considered a junior synonym of $G$. cultrata limbata, following the previously mentioned authors.

\section{Globorotalia scitula group}

This wide and heterogeneous group has, in part, already been taxonomically subdivided (e.g., G. scitula subscitula Conato, $G$. scitula gigantea Blow, $G$. scitula ventriosa Ogniben, G. quinifalcata Saito and Maya), and in part is not yet defined. Solution of the numerous problems concerning the evolution-controlled versus the ecology-controlled changes observed in this complex group of planktonic foraminifers is beyond the purpose of this paper.

\section{Globorotalia siakensis Le Roy}

(Plate 4, Figures 9, 10)

The taxon is ubiquitous, and is common at Site 372 from Core 13 to Sample $9-2,60-62 \mathrm{~cm}$. Populations assigned to this taxon have

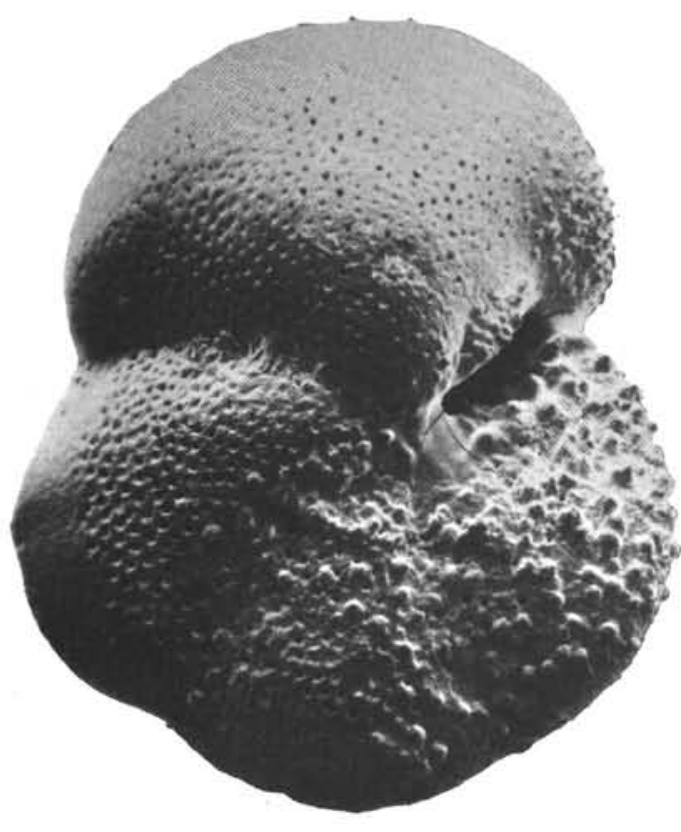

$100 \mu \mathrm{m}$

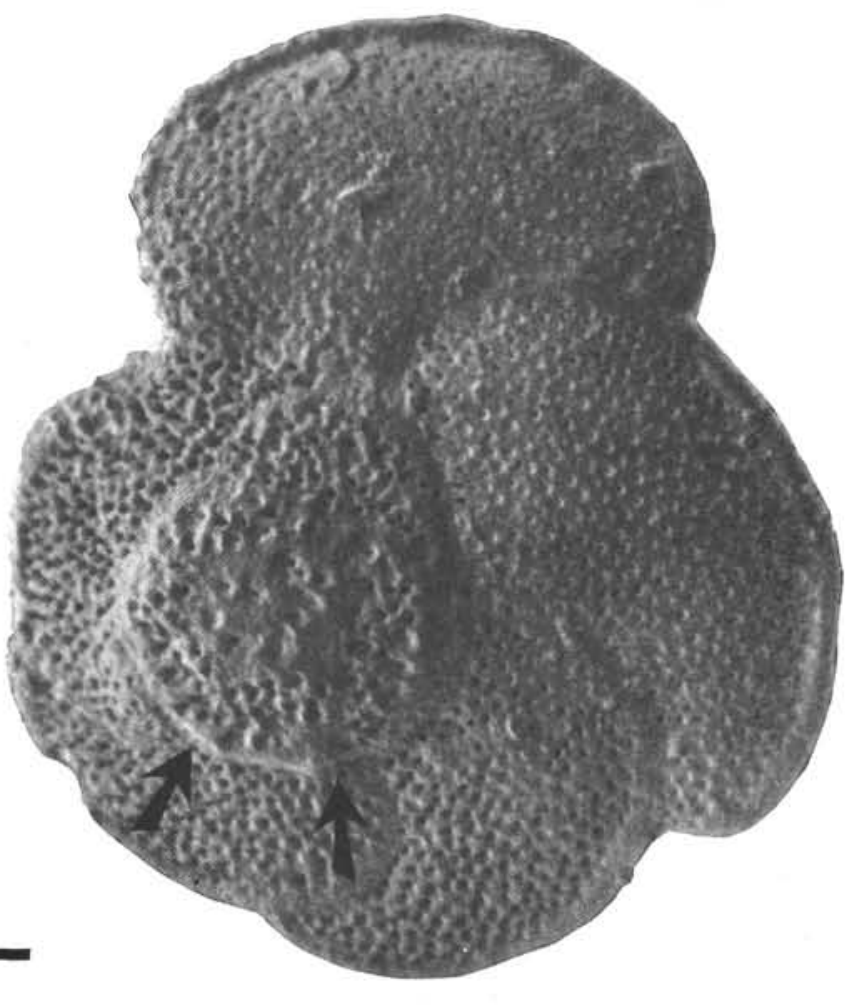

Figure 5. Two large specimens of Globorotalia ex gr. cultrata from Sample 372-13-6, 40-42 cm. The specimen in umbilical view (left) shows a large imperforate carina. The arrows on the specimen in spiral view (right) point to the limbated spiral suture extending beyond the last formed whorl. Serravallian, Zone N.13. 
been examined also from the underlying interval, down to Core 46, which is Burdigalian. We found that this taxon shows, besides high variability in the various samples, progressive modifications of (1) the dimensions of the test and of the umbilicus, and (2) the shape of the chambers and their degree of overlapping. Particularly in the interval here investigated, G. siakensis often includes large specimens with 6 or 7 chambers in the final whorl, wide, open umbilicus, globular chambers well separated one from the other, and distinct apertural lip, rather similar to G. acostaensis humerosa. This is considered a case of homeomorphism, since the two taxa, besides differing in some features, such as the shape of the aperture (which is a low arch bordered by a thin lip in $G$. acostaensis humerosa, a wide arch usually without, but occasionally with, an apertural lip in $G$. siakensis), have non-overlapping stratigraphic ranges. Indeed, $G$. siakensis becomes extinct (according to Blow, 1969) at the top of Zone N.14, whereas $G$. acostaensis humerosa evolves from $G$. acostaensis acostaensis (see Plate 4, Figures 5,6) in the upper part of Zone N.16 (Blow, 1969; Cita and Blow, 1969).

In our view, a prerequisite for distinction of the taxon under discussion should be a biometrically founded study of its variability in time and space.

Globorotalia aff. suterae Catalano and Sprovieri (Plate 4, Figures 1-3)

Sparse specimens referred to this taxon occur in some samples from the interval yielding reworked planktonic foraminifers at Site 372. They differ from $G$. suterae in their tighter coiling, less open umbilicus, more flattened spiral side, chambers less hemispherical in shape in spiral view, more flattened and more elongated tangentially, and in having a lower aperture, slit-like.

$G$. aff. suterae also has a stratigraphic range slightly different from that of G. suterae.According to the zonal scheme of d'Onofrio et al. (1975), the former is restricted to the upper part of the $G$. continuosa Subzone, whereas the latter first occurs in the $G$. suterae Subzone.

\section{Globorotalia ef. tumida plesiotumida Banner and Blow} (Plate 5, Figure 12)

Specimens similar to the holotype of G. tumida plesiotumida have been recorded in Sample 5-1, 125-127 cm at Site 375. They differ from it essentially in having a less convex umbilical side and tighter whorls. We cannot rule out, however, that these forms may represent a primitive form of Banner and Blow's subspecies (see Berggren and Poore, 1974). The material here examined is not considered suitable to solve the problem of the controversial occurrence of $G$. tumida plesiotumida in upper Miocene sediments from the Mediterranean. The taxon has been illustrated several times (see Catalano and Sprovieri 1971; Mazzola, 1971 inter alias) from the land record, as well as from the deep-sea record (Cita, 1973); but some authors, including Bizon and Bizon (1972), deny its occurrence in the Mediterranean area.

\section{Globorotaloides falconarae Giannelli and Salvatorin}

(Plate 4, Figures 12, 13)

Typical specimens of this species, recently described from the Miocene of Sicily (Gianelli and Salvatorini, 1976), occur in the interval with reworked planktonic foraminifers at Site 372. At Site 375 we only found immature specimens, in the Globorotalia onthogenetic stage.

\section{Cassigerinella chipolensis (Cushman and Ponton)}

$$
\text { (Figure 6) }
$$

Sparse, small, typical specimens of this taxon occur in one of the samples examined from the lower part of Section 2, Core 9, Site 372. If these specimens are not reworked, they represent one more indication that the marls under discussion are Serravallian, since $C$. chipolensis becomes extinct in Zone N.13 (Blow, 1969).

\section{ACKNOWLEDGMENTS}

The present study has been partly supported by Consiglio Nazionale delle Ricerche of Italy, Comitato 05.

We are very grateful to T. Saito, Lamont-Doherty Geological Observatory of Columbia University, for interesting and useful discussions on the Site 372 biostratigraphy.

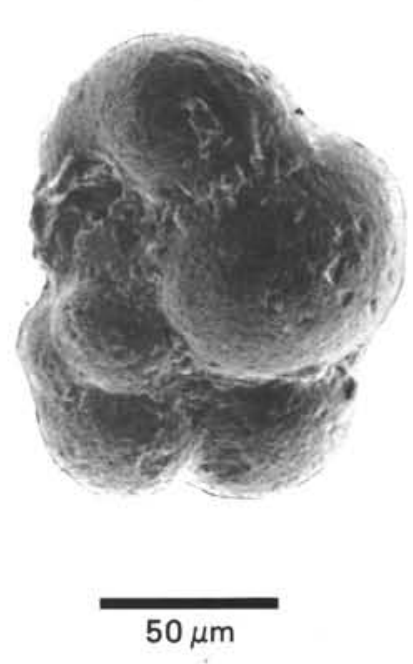

Figure 6. Cassigerinella chipolensis /Cushman and Ponton). Sample 372-9-2, 126-127 cm. Serravallian, Zone N.13.

We sincerely thank Agostino Rizzi and Giovanni Chiodi, University of Milano, for their appreciated work of photographers.

A final draft of the present paper has been critically reviewed by I. Premoli Silva, University of Milano, and b. W. A. Berggren, Woods Hole Oceanographic Institution.

\section{REFERENCES}

Banner, F. T. and Blow, W. H., 1960. Some primary types of species belonging to the superfamily Globigerinaceae: Contrib. Cush. Found. Foram. Res., v. 11, p. 1-41.

Berggren, W. A., and Amdurer, M., 1973. Late Paleogene (Oligocene) and Neogene foraminiferal biostratigraphy of the Atlantic Ocean (lat $30^{\circ} \mathrm{N}$ to lat. $30^{\circ} \mathrm{S}$ ): Riv. Ital. Paleont. Strat., v. 79 , p. 337-392.

Berggren, W. A. and Poore, R. Z., 1974. Late Miocene early Pliocene planktonic foraminiferal biochronology: Globorotalia tumida and Sphaeroidinella dehiscens Lineages: Riv. Ital. Paleont. Strat., v. 80, p. 689-698.

Bizon, G. and Bizon, J.-J., 1972. Atlas des principaux foraminifères planctoniques du Bassin Méditerranéen. Oligocène à Quaternaire. Technip, p. 1-316.

Blow, W. H., 1959. Age, correlation and biostratigraphy of the upper Tokuyo (San Lorenzo) and Pozon Formations, Eastern Falcon, Venezuela: Am. Paleontol. Bull., v. 39, p. 67-252.

1969. Late middle Eocene to Recent planktonic foraminiferal biostratigraphy: First Intern. Conf. Plankt. Microf. Proc., Geneva 1967, p. 199-421.

Bolli, H. M., 1957. Planktonic foraminifera from the Oligocene-Miocene Cipero and Lengua Formations of Trinidad, B.W.I.: U.S. Nat. Mus. Bull. 15, p. 97-123.

Bronnimann, P. and Resig, J., 1971. Neogene Globigerinacean biochronologic time-scale of the Southwestern Pacific. In Winterer, E. L., Riedel, W. R., et al., Initial Reports of the Deep Sea Drilling Project, Volume 7: Washington (U.S. Government Printing Office), p. 12351470.

Catalano, R. and Sprovieri, R., 1969. Stratigrafia e micropaleontologia dell'intervallo tripolaceo di Torrente Røssi 
(Enna): Atti Acc. Gioenia Sc. Nat. Catania, v. 7, p. 513527.

Catalano, R. and Sprovieri, R., 1971. Biostratigrafia di alcune serie saheliane (Messiniano inferiore) in Sicilia: Second Plankt. Conf. Proc., Roma 1970, p. 513-527.

Cita, M. B., 1971. Biostratigraphy, chronostratigraphy and paleoenvironment of the Pliocene of Cape Verde (North Atlantic): Rev. Micropal., v. 14, p. 17-42.

1973. Inventory of biostratigraphic findings and problems. In Ryan, W. B. F., Hsü, K. J., et al, Initial Reports of the Deep Sea Drilling Project, Volume 13: Washington (U.S. Government Printing Office), p. 10451074.

Cita, M. B. and Blow, W. H., 1969. The biostratigraphy of the Langhian, Serravallian and Tortonian Stages in the type-sections in Italy: Riv. Ital. Paleont. Strat., v. 75, p. 549-603.

Cita, M. B., Premoli Silva, I. and Rossi, R., 1965. Foraminiferi planctonici del Tortoniano-tipo: Riv. Ital. Paleont. Strat., v. 71, p. 217-308.

Cita, M. B., Stradner, H., and Ciaranfi, N., 1973. Biostratigraphical investigations on the Messinian stratotype and on the overlying "Trubi" Formation: Riv. Ital. Paleont. Strat., v. 79, p. 393-446.

Colalongo, M. L., 1970. Apunti biostratigrafici sul Messiniano: Giorn. Geol., v. 36, p. 515-537.

D'Onofrio, S., Giannelli, L., Iaccarino, S., Morlotti, E., Romeo, M., Salvatorini, G., Sampo', M., and Sprovieri, R., 1975. Planktonic foraminifera of the Upper Miocene from some italian sections and the problem of the lower boundary of the Messinian: Boll. Soc. Paleont. Ital., v. 14, p. 177-196.

Drooger, C. W. (Ed.), 1973. Messinian Events in the Mediterranean. Kon. Nederl. Akad. Wetens.: Amsterdam (North. Holland Publishing Company), p. 1-272.

Giannelli, L. and Salvatorini, G., 1975. I Foraminiferi planctonici dei sedimenti terziari dell' Arcipelago maltese. II. Biostratigrafia di: "Blue Clay," "Greensand" and "Upper Coralline Limestone": Atti Soc. Tosc. Sc. Nat., Mem., v. 82 , p. $20-42$.

1976. Alcune nuove specie di Foraminiferi planctonici del Miocene: Boll. Soc. Paleont. Ital., v. 15, p. $167-$ 174.
Gianotti, A., 1953. Microfaune della serie tortoniana del Rio Mazzapiedi-Castellania (Tortona-Alessandria): Riv. Ital. Paleont. Strat., Mem. VI, p. 167-308.

Jenkins, D. G. and Orr, W. N., 1972. Planktonic foraminiferal biostratigraphy of the eastern equatorial Pacific DSDP Leg IX. In Hays, J. D. et al., Initial Reports of the Deep Sea Drilling Project, Volume 9: Washington (U.S. Government Printing Office), p. 1059-1193.

Mazzola, G., 1971. Les foraminiferes planctoniques du MioPliocène de l'Algérie nord-occidentale: Second Plankt. Conf. Proc., Roma 1970, p. 787-812.

Postuma, J. A., 1971. Manual of Planktonic foraminifera: New York (Elsevier Publ. Co.), p. 1-420.

Ryan, W. B. F., Cita, M. B., Dreyfus Rawson, M., Burckle, L. H., and Saito, T., 1974. A paleomagnetic assignment of Neogene stage boundaries and the development of isochronous datum planes between the Mediterranean, the Pacific and Indian Oceans in order to investigate the response of the World Ocean to the Mediterranean "Salinity Crisis": Riv. Ital. Paleont. Strat., v. 80, p. 631688.

Ryan, W. B. F., Hsü, K. J., et al., 1973. Initial Reports of the Deep Sea Drilling Project, Volume 13: Washington (U.S. Government Printing Office).

Selli, R., 1960. Il Messiniano Mayer-Eymar. Proposta di un neostratotipo: Giorn. Geol., v. 2, p. 1-33.

Sonnenfeld, P., 1974. The Upper Miocene evaporitic basins in the Mediterranean region. A study in paleo-oceanography: Geol. Rundsch., v. 63, p. 1133-1172.

Srinivasan, M. S., 1975. Middle Miocene planktonic foraminifera from the Hut Bay Formation, Little Andaman Island, Bay of Bengal: Micropaleontology, v. 21, p. 133150.

Stainforth, R. M., Lamb, J. L., Luterbacher, H., Beard, J. H., and Jeffords, R. M., 1975. Cenozoic planktonic foraminiferal zonation and characteristics of index forms: The Univ. Kansas Paleont. Contrib., v. 62, p. 1-425.

Tjalsma, R. C., 1971. Stratigraphy and foraminifera of the Neogene of the Eastern Guadalquivir Basin (Southern Spain): Utrecht Micropal. Bull., v. 4, p. 1-161.

Zachariasse, W. J., 1975. Planktonic foraminiferal biostratigraphy of the Late Neogene of Crete (Greece): Utrecht Micropal. Bull., v. 11, p. 1-171. 


\section{PLATE 1}

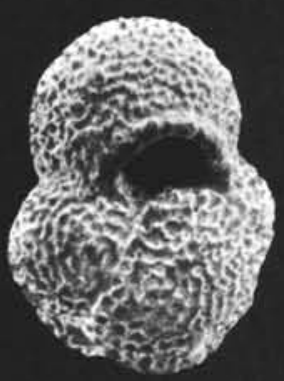

1

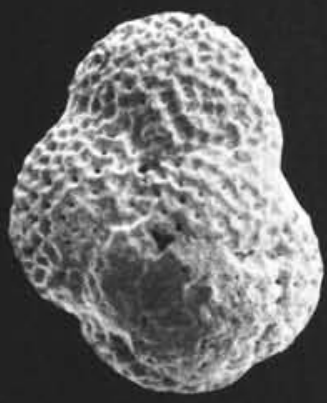

6

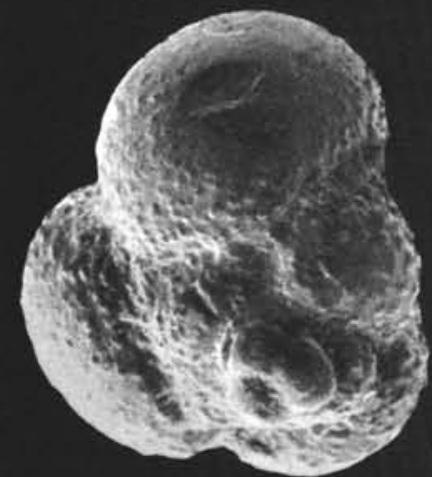

10

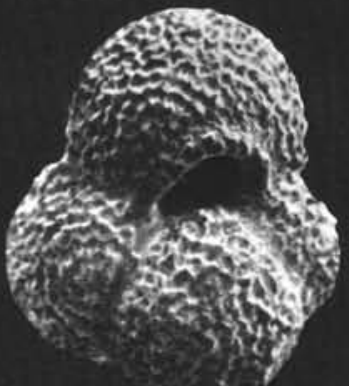

2

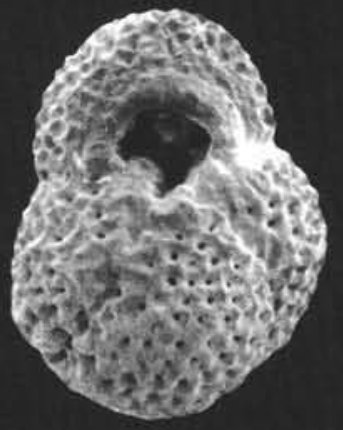

7

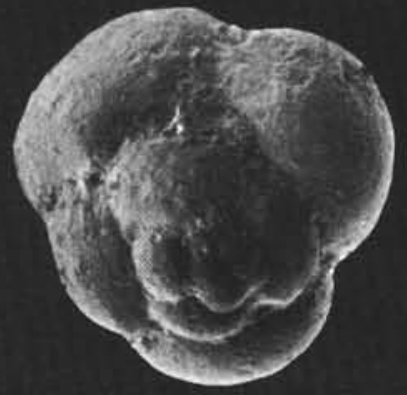

11

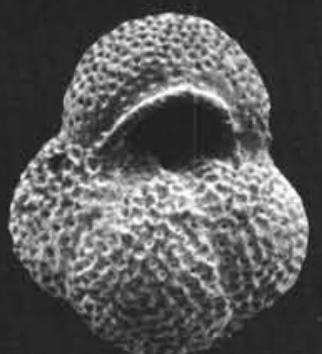

3

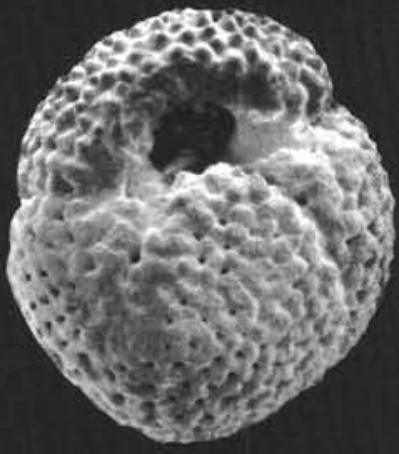

8

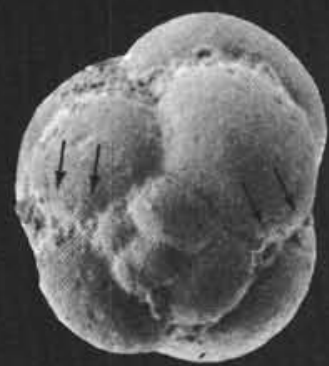

12
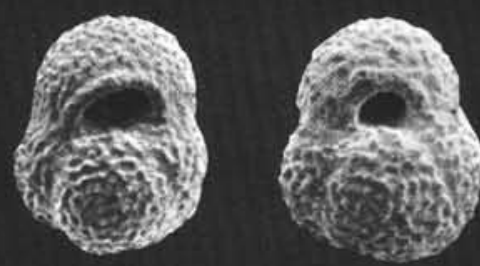

5

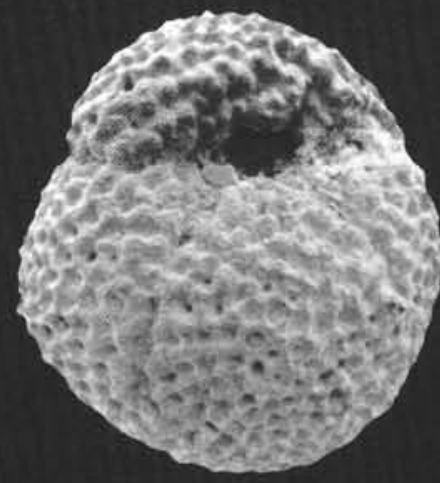

9

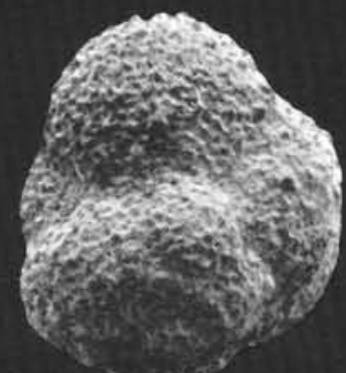

13

Figures 1-3

Figures 4, 5

Figures 6, 7

Figures 8, 9

Figures 10, 11

Figure 12

Figure 13
Globigerina druryi Akers, umbilical views. Sample 372-13-4, 40-42 cm. Serravallian, Zone N.13. Small specimens identified as Globigerina, "druryi-nepenthes," umbilical views. Sample 372-9-2, 60-62 cm, Serravallian, Zone N.13.

Globigerina nepenthes Todd. Sample 375-4-1, 125-127 cm. Upper Tortonian, Zone N.17.

6. C. Spiral view.

7.Umbilical view.

Globigerinoides bollii Blow, umbilical views. Sample 375-5, CC. Tortonian, Zone N.16.

Candeina nitida praenitida Blow. Spiral views. Sample 375-4-2, 60-62 cm. Upper Tortonian, Zone N.17.

Candeina nitida nitida d'Orbigny, spiral view. The arrows point to the multiple apertures. Sample 375-4-2, 60-62 cm. Upper Tortonian, Zone N.17.

Globigerina digitata praedigitata Parker, spiral view slightly oblique. Sample 375-5, CC, Upper Tortonian, Zone N.16. 

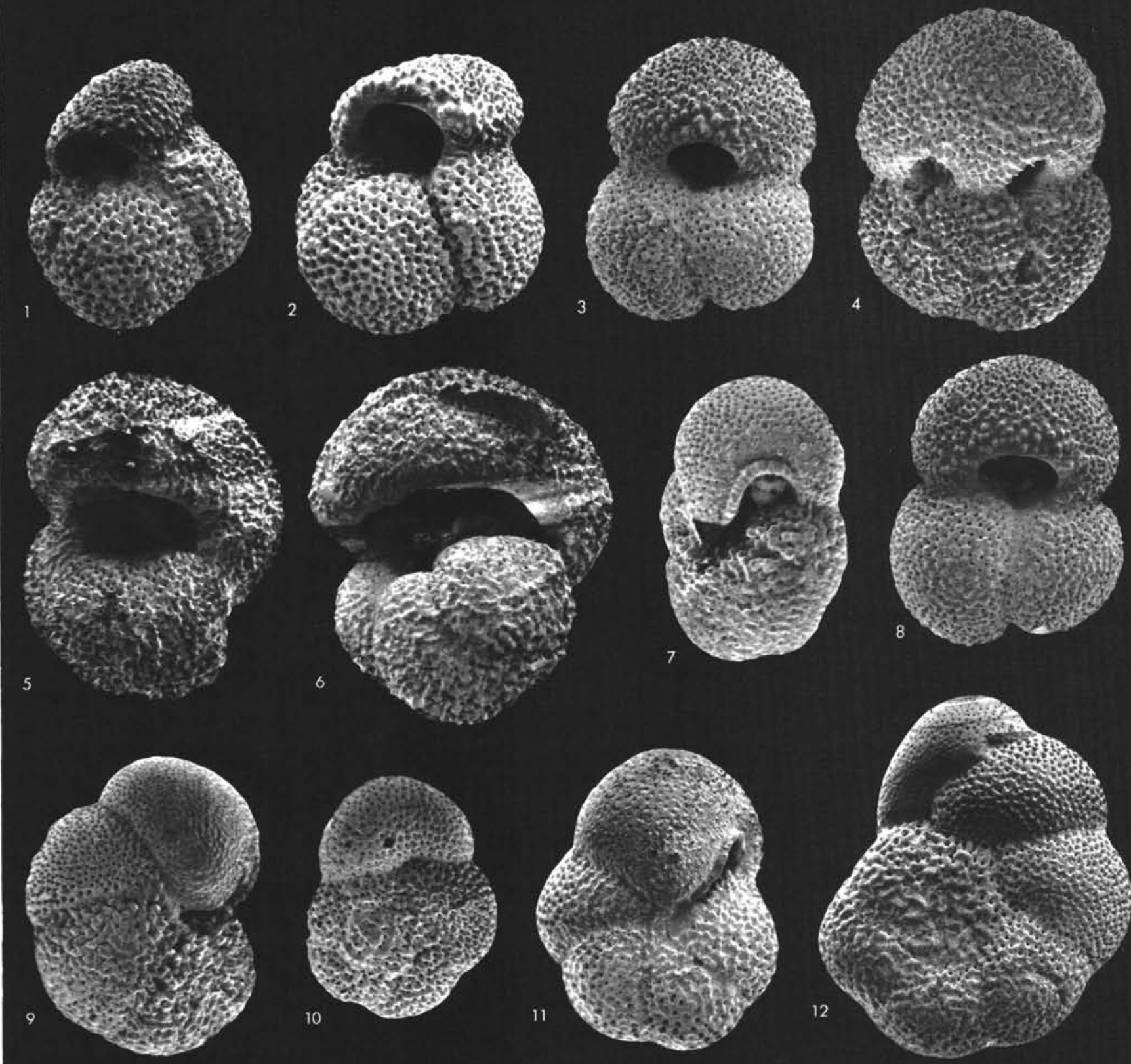

$100 \mu \mathrm{m}$

Figures 1, 2 Globigerinoides obliquus extremus Bolli and Bermudez, umbilical views. Sample 375-4-1, 125-127 $\mathrm{cm}$. Upper Tortonian, Zone N.17.

Figures 3, 4, 8 Globigerinoides subquadratus Bronnimann. Sample 372-9-4, 30-32 cm. Serravallian, Zone N.13. 3,8 . Umbilical views.

4. Sprial view.

Figures 5, 6 Globigerinopsis aguasayensis Bolli. Apertural views, slightly oblique. Samples 372-11-1, 90-92 cm (specimen illustrated in Figure 5) and 372-12-6, 30-32 cm (specimen of Figure 6).

Figures 7, 9-12 Globorotalia mayeri Cushman and Ellisor. Sample 372-13-1, 30-32 cm. Serravallian, Zone N.13.

7. Side view.

9, 11. Umbillical view.

10,12 . Spiral view. 


\section{PLATE 3}

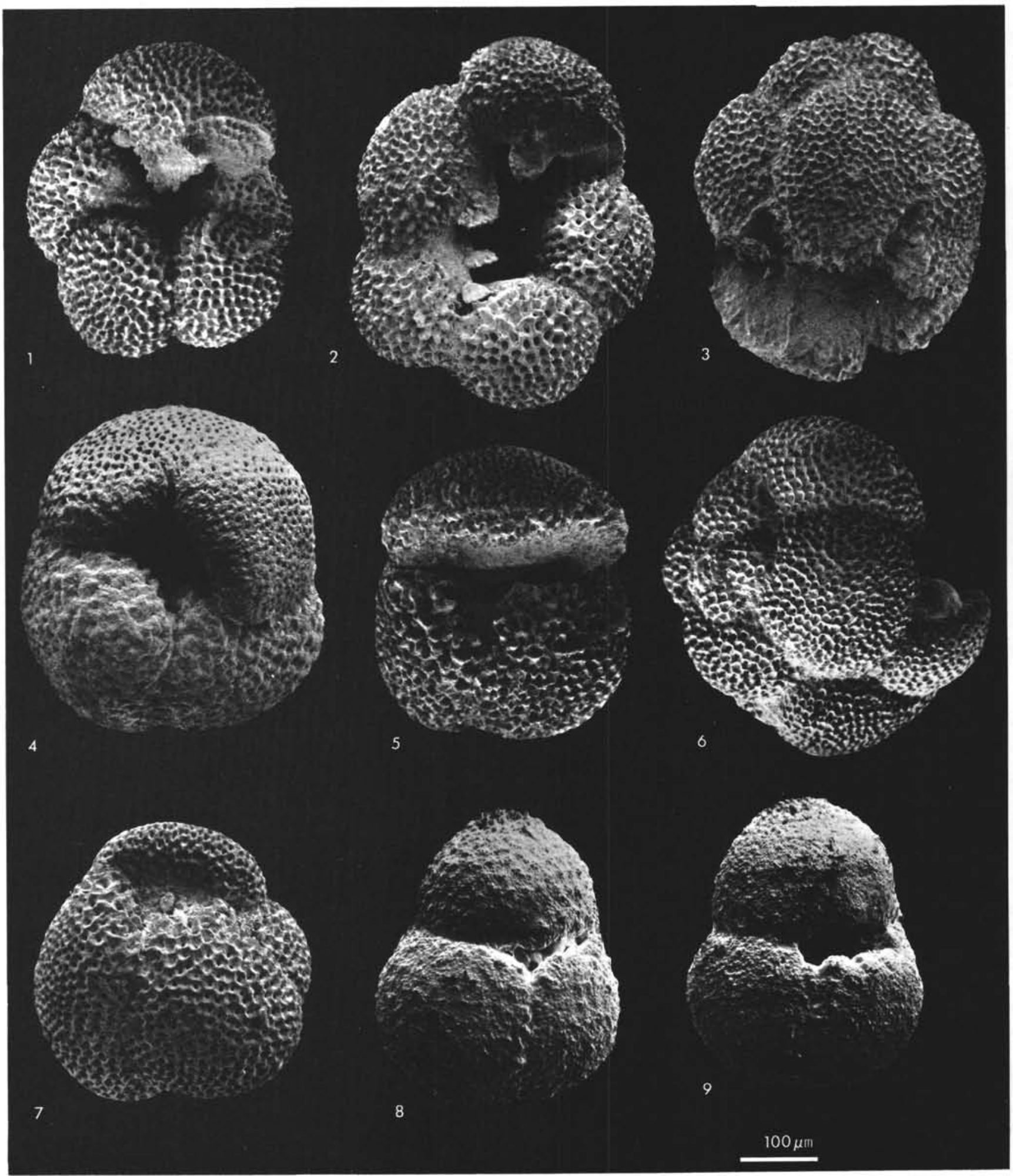

Figures 1, 2 Globoquadrina altispira globosa Bolli, umbilical views. Sample 372-9-3, 80-82 cm. Serravallian, Zone N.13.

Figures 3, 6 Globoquardina altispira altispira (Cushman and Jarvis), lateral views. Sample 372-10-2, 50-52 cm. Figures 4, 7 Globoquadrina dehiscens advena Bermudez, umbilical views. Sample 372-9-4, 30-32 cm. Serravallian, Zone N.13.

Figure 5. Globoquadrina dehiscens dehiscens (Chapman, Parr, and Collins), umbilical view. Sample 372-9-4,

Figures 8, 9 Sphaeroidinellopsis subdehiscens subdehiscens Blow, umbilical views. Sample 372-13-1, 30-32 cm. Serravallian, Zone N.13. 


\section{PLATE 4}

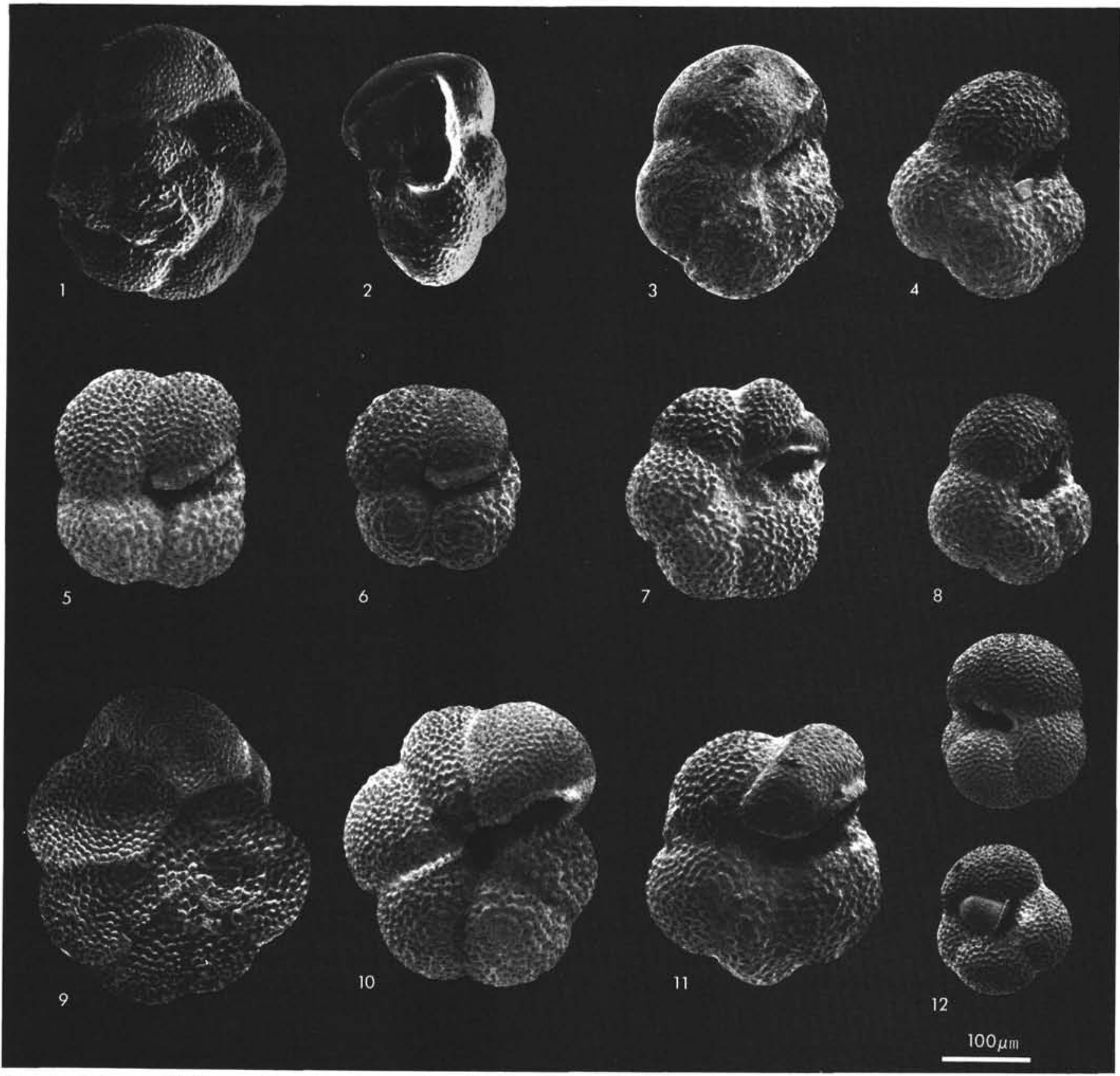

Figures 1-3 Globorotalia aff. suterae Catalano and Sprovieri. Sample 372-4-1, 130-132 cm. Messinan, Zone N.17.

1. Spiral view.

2. Side view.

3. Umbilical view.

Figures 4, 8 Globorotalia continuosa Blow, umbilical views. Sample 372-12-4, 70-72 cm. Serravallian, Zone N.13.

Figures 5, 6 Globorotalia acostaensis acostaensis Blow, umbilical views. Sample 375-5, CC. Tortonian, Zone N.16.

Figures 7, 11 Globorotalia acostaensis humerosa Takayanagi and Saito, umbilical views. Sample 375-4-2, 62-64 cm. Upper Tortonian, Zone N.17.

Figures 9, 10 Globorotalia siakensis Le Roy, Sample 372-13-3, 40-42 cm. Serravallian, Zone N.13.

9. Spiral view.

10. Umbilical view.

Figures 12, 13 Globorotaloides falconarae Giannelli and Salvatorini, umbilical views of immature specimens. Sample $375-7-3,48-50 \mathrm{~cm}$. Tortonian, Zone N.16. 


\section{PLATE 5}

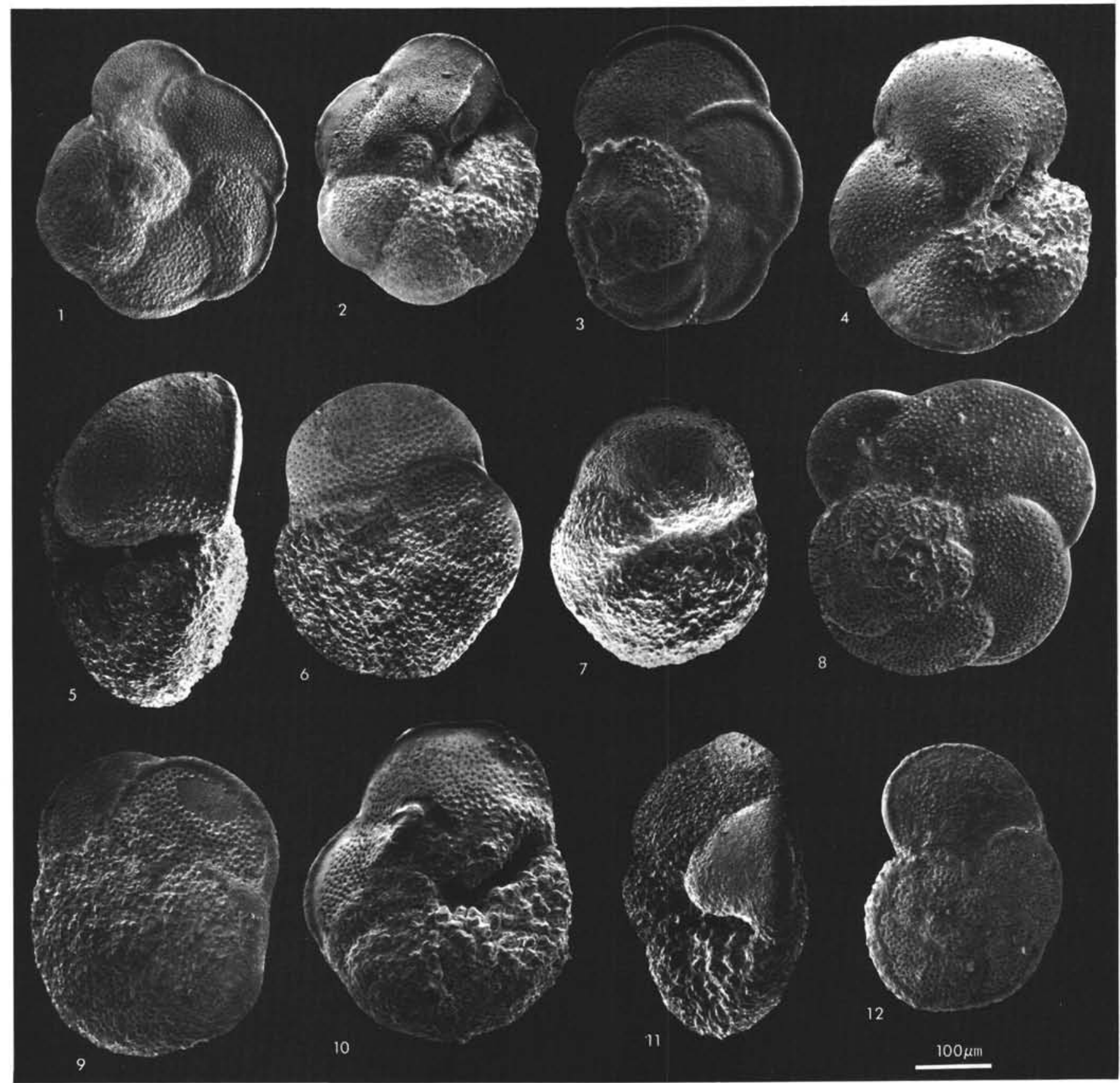

Figures 1-3

Globorotalia gr. cultrata. Sample 372-9-4, 30-32 cm. Serravallian, Zone N.13.

1,3 Sprial view.

2. Umbilical view.

Figures 4, 8 Globorotalia praemenardii praemenardii Cushman and Stainforth. Sample 372-13-6, 40-42 cm.

4. Umbilical view.

8. Spiral view.

Figures 5-7 Globorotalia miozea conoides Walters.

5. Side view (Sample 372-9-4, 30-32 cm)

6. Spiral view (Sample 372-10-2, 50-52 cm)

7. Umbilical view (sample $372-9-4,30-32 \mathrm{~cm}$ ).

Figures 9-11 Globorotalia miozea miozea Finlay. Sample 372-94-4, 30-32 cm. Serravallian, Zone N.13.

9. Spiral view.

10. Umbilical view.

11. Side view.

Figure 12 Globorotalia cf. tumida pleisotumida Blow and Banner, spiral view. Sample 375-4-1, 125-127 cm. Upper Tortonian, Zone N.17. 